\title{
Cancer of the respiratory tract in nickel sinter plant workers: effect of removal from sinter plant exposure
}

\author{
David C F Muir, Ni Jadon, Jim A Julian, Robin S Roberts
}

\begin{abstract}
The risk of death due to cancer of the nose or lung was studied in nickel sinter plant workers during the period after they left the sintering operations. It was found that the excess risk of death from both diseases continued for many years after leaving the sinter plant. No effect of age at first exposure could be found. Possible explanations for the continued risk include an irreversible cellular change or the persistence of carcinogenic nickel compounds in the mucosa.
\end{abstract}

(Occup Environ Med 1994;51:19-22)

An increased risk of death from cancer of the lung and nose was reported by Roberts et al in nickel sinter plant workers in Ontario. ${ }^{12}$ This was similar to previous findings by Doll in nickel workers in Britain. ${ }^{3}$ In an extensive review of available epidemiological studies, an international committee concluded that more than one form of nickel could give rise to lung and nasal cancer. ${ }^{4}$ Both oxidic and sulphidic compounds of nickel as well as soluble nickel increased the risk of these cancers. There was no evidence that metallic nickel was associated with increased risks of lung and nasal cancer, and no substantial evidence was obtained to suggest that occupational exposure to nickel or any of its compounds was likely to produce cancers elsewhere other than in the lung or nose.

The two sintering operations studied by Roberts et al operated between 1948 and 1963 at Copper Cliff (Sudbury) and between 1926 and 1958 at Port Colborne. All male employees of the International Nickel Company (INCO) who had worked for the company in Ontario for six months or more and who had been employed (or been a pensioner) between January 1950 and 31 December 1976 were included in the main study cohort. ${ }^{1}$ In the Port Colborne cohort, because the sintering facility was housed in the same building as the leaching and calcining operations about the same time, and as the job descriptions were not unique to the process, it was impossible to isolate the sintering work experience. Therefore, the Port Colborne sinter plant label used in this test actually refers to the combined leaching, calcining, and sintering operations (see L, C, and $S$ department in Roberts et al). ${ }^{2}$ The increased risk of lung and nasal cancer was associated with exposure to very high concen- trations of airborne nickel compounds in the sinter operations. No similar increased risks were identified in other parts of the industry with the exception of certain groups of underground miners (probably unrelated to nickel) and certain defined occupations in the copper refinery.

The purpose of the present investigation was to determine the risk of death from cancer of the lung or nose in sinter plant workers in the years after they had left that operation. The matter is of obvious medical importance in terms of any advice or assistance that can be given to these men, and may also be relevant to an understanding of the nature of nickel carcinogenesis.

\section{Methods}

Sinter plant workers identified in the study by Roberts et al who had spent more than one month in the sintering operation were followed up to determine their vital status in the years after they left the sinter plant. ${ }^{12}$ Information on mortality was obtained by computerised record linkage to the Canadian Mortality Data Base up to the end of $1984 .^{12}$ The end of employment in the sinter plant was not synonymous with removal from all nickel exposure, as many were later employed in other parts of the industry. As already mentioned, however, no excess risk of cancer was noted in these areas by Roberts et al. ${ }^{12}$ Cause specific age and year standardised mortality ratios (SMRs) were calculated with respect to Ontario provincial mortality. Also, the excess risk due to lung and nasal cancer attributable to occupational exposure was calculated by subtracting the expected number of cases from those observed and dividing by the person-years at risk. The scaled value obtained is the excess mortality rate (EMR) per 10000 person-years. This is also called the standardised risk difference (SRD). The EMR was chosen for presentation of the data because, as reviewed in the discussion section, this may have advantages over the SMR when analysing excess risks in occupational cohorts.

Tables 1 and 2 present the results of this analysis for lung and nasal cancer, in which mortality is stratified by years since last exposure in the sinter operation (TSLE), by duration of exposure, and by age at first exposure. Special attention was given to long term workers with more than five years of exposure in the sinter plant. The overall risk of death from lung or nasal cancer attributable to 
Table 1 Lung cancer deaths after $\geqslant 5$ years of exposure

\begin{tabular}{|c|c|c|c|c|c|c|c|c|c|c|}
\hline \multirow{2}{*}{$\begin{array}{l}\text { Time } \\
\text { since } \\
\text { last } \\
\text { exposure } \\
(y)\end{array}$} & \multicolumn{5}{|c|}{ Age at first exposure $<30 y$} & \multicolumn{5}{|c|}{ Age at first exposure $\geqslant 30 y$} \\
\hline & Observed & Expected & $\begin{array}{l}\text { Person- } \\
\text { years }\end{array}$ & $S R D^{*}$ & $\left(95 \% C I^{\star}\right)$ & Observed & Expected & $\begin{array}{l}\text { Person- } \\
\text { years }\end{array}$ & $S R D^{*}$ & $\left(95 \% C I^{*}\right)$ \\
\hline \multicolumn{11}{|c|}{ Copper Cliff sinter plant } \\
\hline $\begin{array}{c}0-9 \\
10-19 \\
20-29 \\
30-39\end{array}$ & $\begin{array}{l}6 \\
9 \\
2 \\
0\end{array}$ & $\begin{array}{l}0 \cdot 181 \\
0.833 \\
0.442 \\
0.002\end{array}$ & $\begin{array}{r}1362 \cdot 8 \\
1246 \cdot 9 \\
345 \cdot 0 \\
0 \cdot 8\end{array}$ & $\begin{array}{r}42 \cdot 70 \\
65 \cdot 50 \\
45 \cdot 16 \\
-25 \cdot 00\end{array}$ & $\begin{array}{l}(34.05 \text { to } 51.35) \\
(45.21 \text { to } 85.79) \\
(-8.26 \text { to } 98.57) \\
(-1574.52 \text { to } 1524.52)\end{array}$ & $\begin{array}{r}4 \\
12 \\
1 \\
0\end{array}$ & $\begin{array}{l}0.687 \\
1.483 \\
0.603 \\
0.0\end{array}$ & $\begin{array}{r}928 \cdot 6 \\
718 \cdot 6 \\
185 \cdot 0 \\
0.0\end{array}$ & $\begin{array}{r}35 \cdot 68 \\
146 \cdot 35 \\
21 \cdot 46 \\
-\end{array}$ & $\begin{array}{l}(10.94 \text { to } 60.42) \\
(99.38 \text { to } 193.33) \\
(-94.89 \text { to } 137.81)\end{array}$ \\
\hline$\geqslant 40$ & $\begin{array}{r}0 \\
17\end{array}$ & $\begin{array}{l}0.0 \\
1.458\end{array}$ & $\begin{array}{r}0 \cdot 0 \\
2955 \cdot 4\end{array}$ & $\overline{52.59}$ & $(41.26$ to 63.91$)$ & $\begin{array}{r}0 \\
17\end{array}$ & $\begin{array}{l}0 \cdot 0 \\
2 \cdot 773\end{array}$ & $\begin{array}{r}0 \cdot 0 \\
1832 \cdot 2\end{array}$ & $\overline{77} \cdot 65$ & $\overline{(52 \cdot 46}$ to $102 \cdot 84)$ \\
\hline \multicolumn{11}{|c|}{ Pon Colborme leaching, calcining, and sintering } \\
\hline $\begin{array}{c}0-9 \\
10-19 \\
20-29 \\
30-39\end{array}$ & $\begin{array}{l}4 \\
5 \\
2 \\
5\end{array}$ & $\begin{array}{l}0.683 \\
1.102 \\
1.044 \\
0.905\end{array}$ & $\begin{array}{r}1173 \cdot 5 \\
1145 \cdot 6 \\
621 \cdot 8 \\
297 \cdot 5\end{array}$ & $\begin{array}{r}28 \cdot 27 \\
34 \cdot 03 \\
15 \cdot 38 \\
137 \cdot 65\end{array}$ & $\begin{array}{l}(8 \cdot 75 \text { to } 47 \cdot 79) \\
(8 \cdot 63 \text { to } 59 \cdot 43) \\
(-30 \cdot 17 \text { to } 60 \cdot 92) \\
(49 \cdot 01 \text { to } 226 \cdot 28)\end{array}$ & $\begin{array}{r}12 \\
3 \\
5 \\
1\end{array}$ & $\begin{array}{l}1 \cdot 324 \\
1.767 \\
1.501 \\
0.837\end{array}$ & $\begin{array}{r}1085 \cdot 2 \\
912 \cdot 6 \\
529 \cdot 8 \\
205 \cdot 8\end{array}$ & $\begin{array}{r}98 \cdot 38 \\
13 \cdot 51 \\
66 \cdot 04 \\
7 \cdot 92\end{array}$ & $\begin{array}{l}(68.99 \text { to } 127 \cdot 77) \\
(-26 \cdot 86 \text { to } 53.89) \\
(1.95 \text { to } 130 \cdot 14) \\
(-115.30 \text { to } 131 \cdot 14)\end{array}$ \\
\hline $\begin{array}{l}\geqslant 40 \\
\text { All }\end{array}$ & $\begin{array}{r}1 \\
17\end{array}$ & $\begin{array}{l}0.350 \\
4.083\end{array}$ & $\begin{array}{r}79 \cdot 8 \\
3318 \cdot 2\end{array}$ & $\begin{array}{l}81.45 \\
38.93\end{array}$ & $\begin{array}{l}(-124.04 \text { to } 286.95) \\
(22.05 \text { to } 55.81)\end{array}$ & $\begin{array}{r}0 \\
21\end{array}$ & $\begin{array}{l}0.143 \\
5.572\end{array}$ & $\begin{array}{r}31 \cdot 0 \\
2764 \cdot 4\end{array}$ & $\begin{array}{r}-46 \cdot 13 \\
55 \cdot 81\end{array}$ & $\begin{array}{l}(-384.25 \text { to } 292 \cdot 00) \\
(32 \cdot 14 \text { to } 79 \cdot 48)\end{array}$ \\
\hline
\end{tabular}

${ }^{\star}$ per 10000 person-years; SRD = standardised risk difference.

occupational exposure (SRD) in these workers was expressed by combining data from both the Copper Cliff and Port Colborne sinter plants (figs 1 and 2).

In general the results show no evidence of a diminution of the risk for as long as 30 to 40 years after leaving the sinter plant. There seems to be no evidence of an effect of age at first exposure although the numbers may be too small to detect such a result.

\section{Discussion}

As previously mentioned, time since leaving the sinter plant was not the same as removal from all exposure to nickel. It is, however, synonymous with working in an area where there has been no documented risk of excess lung or nasal cancer. Therefore, it is reasonable to attribute the sustained risk in these workers to events which took place during their employment in the sintering operation. A complicating factor is that a programme of annual chest radiography and sputum cytology has been provided on a voluntary basis since 1973. At this point, it is not possible to identify individual participants nor to link their names with the epidemiological study. For this reason, the possibility cannot be excluded that the observed risks of death from lung cancer might have been higher, had this programme not been in place. Controlled trials, however, have not so far shown benefits from such interventions in the case of cigarette smokers, ${ }^{5}$ and the pattern of risk of deaths from nasal cancer in our study is similar to those of the lung (figs 1 and 2). For these reasons, it is suggested that the screening programmes for the early detection and treatment of lung cancer probably did not influence the results. Because of limited numbers, further stratification by calendar year of first exposure was not attempted even though there is good evidence that exposures in Copper Cliff changed with time, ${ }^{4}$ and the same may be true in Port Colborne.

Similarly, prolonged risks of death from cancer of the respiratory tract in nickel workers, even after exposure ceased, were reported in Britain. ${ }^{6}$ An effect of age at first exposure was also noted, which we did not find. The numbers in our study were possibly too small to detect such an effect.

Data of this type may contribute to understanding the nature of nickel carcinogenesis. The multistage model of carcinogenesis ${ }^{7}$ supposes that damage to the genetic material proceeds by a series of independent steps and

Table 2 Nasal cancer deaths after $\geqslant 5$ years of exposure

\begin{tabular}{|c|c|c|c|c|c|c|c|c|c|c|}
\hline \multirow{2}{*}{$\begin{array}{l}\text { Time } \\
\text { since } \\
\text { last } \\
\text { exposure } \\
(y)\end{array}$} & \multicolumn{5}{|c|}{ Age at first exposure $<30 y$} & \multicolumn{5}{|c|}{ Age at first exposure $\geqslant 30 y$} \\
\hline & Observed & Expected & $\begin{array}{l}\text { Person- } \\
\text { years }\end{array}$ & $S R D^{*}$ & $\left(95 \% C I^{*}\right)$ & Observed & Expected & $\begin{array}{l}\text { Person- } \\
\text { years }\end{array}$ & $S R D^{*}$ & $\left(95 \% C I^{*}\right)$ \\
\hline \multicolumn{11}{|c|}{ Copper Cliff sinter plant } \\
\hline $\begin{array}{l}0-9 \\
10-19 \\
20-29 \\
30-39 \\
\geqslant 40 \\
\text { All }\end{array}$ & $\begin{array}{l}0 \\
1 \\
0 \\
0 \\
0 \\
1\end{array}$ & $\begin{array}{l}0.007 \\
0.020 \\
0.007 \\
0.0 \\
0.0 \\
0.034\end{array}$ & $\begin{array}{r}1362 \cdot 8 \\
1246 \cdot 9 \\
345 \cdot 0 \\
0 \cdot 8 \\
0 \cdot 0 \\
2955 \cdot 4\end{array}$ & $\begin{array}{r}-0.05 \\
7.86 \\
-0.20 \\
0.0 \\
- \\
3.27\end{array}$ & $\begin{array}{l}(-1.75 \text { to } 1.65) \\
(4.72 \text { to } 11.00) \\
(-6.92 \text { to } 6.52) \\
= \\
(1.54 \text { to } 5.00)\end{array}$ & $\begin{array}{l}0 \\
4 \\
0 \\
0 \\
0 \\
4\end{array}$ & $\begin{array}{l}0.016 \\
0.021 \\
0.005 \\
0.0 \\
0.0 \\
0.042\end{array}$ & $\begin{array}{r}928 \cdot 6 \\
718.6 \\
185.0 \\
0.0 \\
0.0 \\
1832 \cdot 2\end{array}$ & $\begin{array}{l}-0.17 \\
55 \cdot 37 \\
-0 \cdot 27 \\
= \\
\overline{21} \cdot 60\end{array}$ & $\begin{array}{l}(-3.95 \text { to } 3.60) \\
(49.78 \text { to } 60.96) \\
(-10.87 \text { to } 10.32) \\
= \\
(\overline{18.50} \text { to } 24.70)\end{array}$ \\
\hline \multicolumn{11}{|c|}{ Port Colborme leaching, calcining, and sintering } \\
\hline $\begin{array}{l}0-9 \\
10-19 \\
20-29 \\
30-39 \\
\geqslant 40 \\
\text { All }\end{array}$ & $\begin{array}{l}4 \\
0 \\
0 \\
1 \\
1 \\
6\end{array}$ & $\begin{array}{l}0.017 \\
0.024 \\
0.019 \\
0.012 \\
0.003 \\
0.075\end{array}$ & $\begin{array}{r}1173 \cdot 5 \\
1145 \cdot 6 \\
621 \cdot 8 \\
297 \cdot 5 \\
79 \cdot 8 \\
3318 \cdot 2\end{array}$ & $\begin{array}{c}33.94 \\
-0.21 \\
-0.31 \\
33.21 \\
124.94 \\
17.86\end{array}$ & $\begin{array}{l}(30.86 \text { to } 37.02) \\
(-3.96 \text { to } 3.54) \\
(-6.45 \text { to } 5.84) \\
(23.00 \text { to } 43.42) \\
(105.91 \text { to } 143.96) \\
(15.57 \text { to } 20.14)\end{array}$ & $\begin{array}{r}5 \\
4 \\
3 \\
1 \\
0 \\
13\end{array}$ & $\begin{array}{l}0.037 \\
0.037 \\
0.025 \\
0.009 \\
0.001 \\
0.109\end{array}$ & $\begin{array}{r}1085 \cdot 2 \\
912 \cdot 6 \\
529 \cdot 8 \\
205 \cdot 8 \\
31 \cdot 0 \\
2764 \cdot 4\end{array}$ & $\begin{array}{r}45 \cdot 73 \\
43 \cdot 43 \\
56 \cdot 15 \\
48 \cdot 15 \\
-0 \cdot 32 \\
46 \cdot 63\end{array}$ & $\begin{array}{l}(40.82 \text { to } 50 \cdot 65) \\
(37.58 \text { to } 49 \cdot 27) \\
(47.88 \text { to } 64.43) \\
(35.38 \text { to } 60.93) \\
(-28.60 \text { to } 27.95) \\
(43.32 \text { to } 49.94)\end{array}$ \\
\hline
\end{tabular}

*per 10000 person-years; SRD = standardised risk difference. 
Figure 1 Combined data from Copper Cliff and Port Colborne to illustrate the pattern of risk of death from lung cancer in the years after leaving the sinter plant. SRD = standardised risk difference; $O B S=$ observed deaths; $E X P=$ expected deaths.

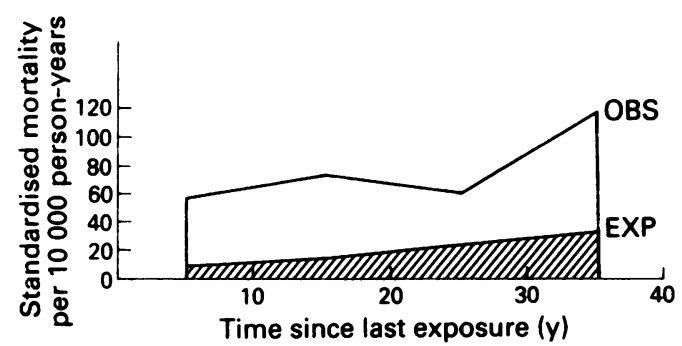

that occupational carcinogens may affect only one stage. A single cell gives rise to a malignant tumour only after it has undergone a number of sequential, heritable, changes. This transformation period is followed by a promotion and rapid growth period in which the transformed cell produces a colony of descendants by rapid cell division. Initiators affect the first stages and have a long latency. Co-carcinogens or promoters act at a later stage and have a shorter latency. The two types of hazards have different characteristics. The excess risk from an initiator depends primarily on time since first exposure and continues to rise even after exposure to that carcinogen ceases. The excess risk following a carcinogen affecting the penultimate stage depends on age at first exposure, older exposures being worse, and the excess incidence remains constant after exposure ceases. ${ }^{8}$

In applying these concepts to sets of human data, Bell and Coleman compared the usefulness of different methods of expressing risk. ${ }^{7}$ From computer generated models, they concluded that the excess death rate (EMR or SRD) was preferable because the more familiar SMR contained two componentsthe excess attributable risks, and the underlying mortality to be expected in the nonexposed population. From fig 1, it is clear that the excess deaths have stayed almost constant in the years after exposure to the sintering operation ceased. The rising expectation of death from lung cancer due to other causes, mainly cigarette smoking, results in a lower SMR after 30 years. As an expression of risk the SMR would thus suggest that the risk has fallen whereas the SRD provides an opposite result.

Application of the multistage model to our data provides conflicting evidence concerning the nature of nickel carcinogenesis. We could

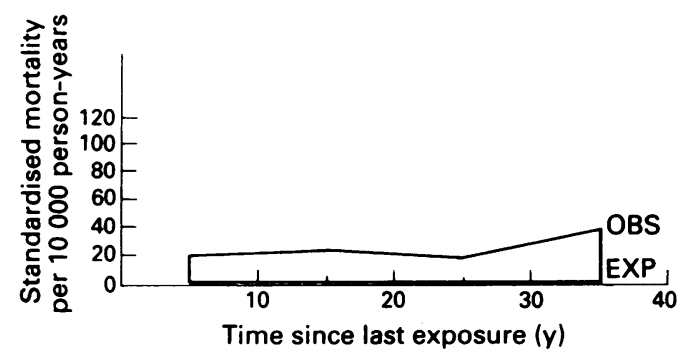

detect no effect of age at first exposure; however, this may be the result of small numbers. We did not find an increasing risk after exposure ended. The possibility that this might, in principle, be the effect of a preventive screening programme in the case of lung cancer has already been discussed. It is possible to conclude only that the risk for both diseases is prolonged for many years after exposure ends without being able to determine the likely stage at which nickel compounds have a carcinogenic effect. Conflicting results were also reported by Kaldor et al who consider that the mechanisms for lung and nasal cancer produced by nickel might turn out to be different. ${ }^{6}$ The persistence of an excess risk after the end of exposure is very similar to that reported in cigarette smokers who stop smoking. ${ }^{8}$

The possibility that slow tumour growth had already started before exposure ended must also be considered. This could certainly effect mortality in the early years after exposure. Nasal cancers however, and also many lung cancers contain rapidly dividing cells which make this unlikely to be an issue 30 or 40 years after exposure. Another relevant factor might have practical implications. The assumption has been made that exposure to carcinogenic nickel compounds ended when the workers left the sinter plant. Their employment in other parts of the industry has already been discussed. There is, however, an alternative explanation that might account for an ongoing carcinogenic risk. In studies of retired nickel workers where biopsies of the nasal mucosa have been carried out, substantial amounts of nickel were detected. ${ }^{19}$ The data were too limited to provide firm information on the rate of removal of nickel, but certainly for eight or nine years after exposure ended, there was excess nickel in the nasal mucosa. It could not be seen by electron microscopy and the precise anatomical site remains unknown. The nickel is probably submucosal because of the rapid cell turnover in the mucosa itself. Whether it is in a particulate form or bound to protein remains unknown. There are no data on the nickel content of the bronchial mucosa in nickel workers.

Persisting nickel deposits could act as continuing carcinogens. A minor effect could be due to delayed nasal mucosal clearance of other particulate carcinogens as soluble nickel compounds diminish frequency of ciliary beats. 11

From the practical point of view, it is important to stress that these workers continue to be at excess risk of death from lung and nasal cancer for many years after leaving exposure. There is no good evidence that the excess risk is diminished with time. Efforts to mitigate the effects are of great importance despite the disappointing results of screening in the case of lung cancer. In this instance, the validity of the multistage model for carcinogens ${ }^{7}$ has practical consequences. If the continuing risk is due to changes in the genetic material, which are irreversible, then 
early detection or attempts to improve repair mechanisms and to avoid further carcinogenic insults are the obvious approach. If there is a real possibility that it is due in part to persistence of nickel in the submucosa, then, perhaps, attempts to remove the deposits of nickel might have a part in a preventive programme. The removal of nickel by the local application of a chelating agent is one such possibility. This would not, however, be effective if the nickel is in particulate form. This was investigated by placing small quantities of fine particles of nickel subsulphide and nickel oxide in $10 \mathrm{ml} 2 \%$ EDTA with the $\mathrm{pH}$ adjusted to $4 \cdot 5,7 \cdot 0,8 \cdot 0$, and $9 \cdot 0$. The suspensions were shaken periodically over four days. Nickel was readily detected in the supranatent fluid, but there was no visible depletion of the solid material.

Although removal from exposure does not lead to a diminution of risk, it is, of course, a most important preventive health measure as the increasing risk with continual exposure is eliminated.

Finally it is stressed that workers who have been employed in an area of the nickel industry where there is an excess risk of cancer must be studied separately from the rest of a cohort of nickel workers. This was the approach used by Roberts et al. ${ }^{2}$ Failure to do so may generate apparent excess risks of cancer in other parts of the process when such risks do not, in fact, exist.
We are grateful to the Joint Occupational Health Committee of the International Nickel Company for support in the develthe solubility of nickel particulates.

1 Roberts RS, Julian JA, Sweezey D, Muir DCF, Shannon HS, Mastromatteo E. A study of mortality in workers engaged in the mining, smelting, and refinery of nickel. I: methodology and mortality by major cause groups. I: methodology and mortality b

2 Roberts RS, Julian JA, Muir DCF, Shannon HS. A study of mortality in workers engaged in the mining, smelting, and refinery of nickel. II:mortality from cancer of the respiratory tract and kidney. Toxicol Ind Health 1989;5:975-93.

3 Doll R. Cancer of the lung and nose in nickel workers. $B$ f Ind Med 1958;15:217-31.

4 Report of the international committee on nickel carcinogenesis in man. Scand $\mathcal{f}$ Work Environ Health 1990; 16:1-81.

5 Fontana RS, Taylor WF. Screening for lung cancer: the Mayo project In: Miller AB, ed. Screening in cancer. VICC technical report services. Vol 40. Gen

6 Kaldor J, Peto J, Easton D, Doll R, Hermon C, Morgan L. Models for respiratory cancer in nickel refinery workers. $\mathcal{F}$ Nat Cancer Inst 1986;77:841-8.

7 Armitage $P$, Doll $\mathbf{R}$. The age distribution of cancer and multistage models of carcinogenesis. Br f Cancer 1954 8:1-12.

8 Peto R. Epidemiology, multistage models and short term mutagenicity tests. In:Hiatt HH, Watson JD, Winsten JA, ed. Origins of human cancer, book C. Cold Spring Harbor Laboratory: 1977, 1403-28.

9 Bell CMJ, Coleman DA. Predicted mortality patterns in cohort study populations exposed to different types of hazard: can SMR's show a dose response? Stat Med 1983;2:363-71.

10 Torjussen W, Andersen I. Nickel concentrations in nasal mucosa, plasma, and urine in active and retired nickel workers. Ann Clin Lab Sci 1979;9:289-98.

11 Adalis D, Gardner DE, Miller F. Cytotoxic effects of nickel on ciliated epithelium. Am Rev Respir Dis 1978; 118:347-53.

\section{Vancouver style}

All manuscripts submitted to Occup Environ Med should conform to the uniform requirements for manuscripts submitted to biomedical journals (known as the Vancouver style.)

Occup Environ Med, together with many other international biomedical journals, has agreed to accept articles prepared in accordance with the Vancouver style. The style (described in full in the $B M Y, 24$ February $1979, \mathrm{p} \mathrm{532}$ ) is intended to standardise requirements for authors.

References should be numbered consecutively in the order in which they are first mentioned in the text by Arabic numerals above the line on each occasion the reference is cited (Manson ${ }^{1}$ confirmed other reports $^{2-5}$. . .). In future references to papers submitted to Occup Environ Med should include: the names of all authors if there are seven or less or, if there are more, the first six followed by et al; the title of journal articles or book chapters; the titles of journals abbreviated according to the style of Index Medicus; and the first and final page numbers of the article or chapter. Titles not in Index Medicus should be given in full.

Examples of common forms of references are:

1 International Steering Committee of Medical Editors, Uniform requirements for manuscripts submitted to biomedical journals. Br Med $\subsetneq 1979 ; 1: 532-5$.

2 Soter NA, Wasserman SI, Austen KF. Cold urticaria: release into the circulation of histamine and eosino phil chemotactic factor of anaphylaxis during cold challenge. N Engl f Med 1976;294:687-90.

3 Weinstein L, Swartz MN. Pathogenic properties of invading micro-organisms. In: Sodeman WA Jr, Sodeman WA, eds Pathologic physiolo of disease. Philadelphia: W B Saunders, 1974:457-72. 